\title{
Dynamic Compaction of Biomaterial Powders
}

\author{
M. Trécant-Viana*,(1), T. Le Neel**, C. Canto-Nicolazo***, E. Champion****, M. Leroy*** and \\ G. Daculsi*
}

* Centre de Recherche sur les Tissus Calcifiés et les Biomatériaux, Faculté de Chirurgie Dentaire, 1 place A. Ricordeau, 44042 Nantes, France

** Laboratoire de Pharmacie Galénique, Faculté de Pharmacie, I rue G. Veil, 44042 Nantes, France *** Laboratoire FORSEM/Composites, IUT, 3 rue du Maréchal Joffre, 44041 Nantes, France **** Laboratoire de Recherche sur les Matériaux Céramiques et Traitements de Surface, Faculté des Sciences, 123 avenue A. Thomas, 87060 Limoges, France

\begin{abstract}
Résumé. La technique de compaction dynamique qui présente l'intérêt de ne nécessiter aucune chaleur extérieure pour la consolidation été utilisée pour compacter de l'hydroxyapatite. Les essais ont montré qu'une précompaction statique de $3 \mathrm{MPa}$ et une compression dynamique d'impact direct de projectile vers $50 \mathrm{~m} / \mathrm{s}$ permettaient d'obtenir des compacts possédant un degré de compaction proche de $65 \%$ et une résistance en tension égale à $12.4 \pm 2.7 \mathrm{MPa}$. Cette résistance du même ordre que celle de compacts obtenus par frittage indiquerait par ailleurs qu'une consolidation se serait produite au cours de la compaction dynamique.
\end{abstract}

\begin{abstract}
Dynamic compaction which requires no external heating for consolidation was used to compact hydroxyapatite. Static precompaction of $3 \mathrm{MPa}$ and dynamic compaction using a projectile velocity of $50 \mathrm{~m} / \mathrm{s}$ resulted in compacts having a compaction degree of $65 \%$ and a tensile strength of $12.4 \pm 2.7 \mathrm{MPa}$. This strength was very close to that obtained with sintered compacts one and seemed to indicate that some interparticle boundaries had been created during dynamic compaction.
\end{abstract}

\section{INTRODUCTION}

Numerous biomaterials have been developped as alternatives to autogenous and allogenous bone grafts. Among these synthetic bone substitutes, calcium phosphate ceramics have been used successfully in orthopedics, dentistry and facial surgery $[1,2,3,4]$. Yet the incorporation of a therapeutic agent (antibiotic, growth factor, etc.) would appear to be of interest for the treatment of certain pathologies, allowing sustained release of the drug in adjacent bone. The conventional ceramic manufacturing process involves consolidation of powder by compaction and heating to achieve sintering of the material. Heating is necessary to strengthen the material but prevents mixing of the therapeutic agent with calcium phosphate powder before compaction. Furthermore crystallinity and morphological features of the powder change with high temperatures $[5,6,7,8]$ and unstable materials alter when heated [7].

Dynamic compaction is a technique used to produce bulk material from metallic powders at room temperature $[9,10,11,12,13,14,15,16,17]$ and appeared to have a potential interest for the elaboration of new bioceramics particularly composites associating calcium phosphates and therapeutic agents. Consolidation is achieved by a shock wave produced by a piston impact or explosives placed around the powder. This wave deforms powder particles so quickly that interparticle melting and welding occur without external heating

The present study determined the quantitative compaction parameters of hydroxyapatite powder and investigated the mechanical characteristics of the compacts.

\section{MATERIALS AND METHODS}

\subsection{Experimental procedure}

Shock compaction parameters were determined using hydroxyapatite powder (Merck, Darmstadt, Germany).

The shock compaction system was positioned horizontally so that static precompaction of the powder had to be performed before firing. The powder was compacted uniaxially in a $20 \mathrm{~mm}$ diameter cylindrical die

(1) Present address: Laboratoire de Pharmacie Galénique. Faculté de Pharmacie, 2 rue du Dr Marcland, 87025 Limoges, France 
using a Testwell-type testing machine (figure 1). Crosshead compaction velocity was kept constant at $10 \mathrm{~mm} / \mathrm{min}$.

The dynamic compaction system is shown in figure 2. The Hopkinson bar apparatus (gas pressure 0 to $2 \mathrm{MPa}$ ) fired a $20 \mathrm{~mm}$ diameter and $86 \mathrm{~mm}$ length projectile into the same lubricated die used for static compaction. Projectile velocity was measured by means of two photodiodes positioned on the gas drive. Strain gauges fixed on the transmission bar permitted the measurement of the transmitted compression wave.

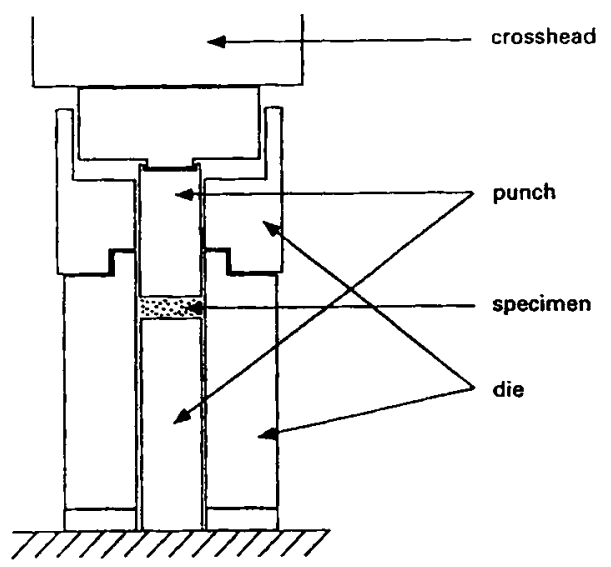

Figure 1: Static precompaction system

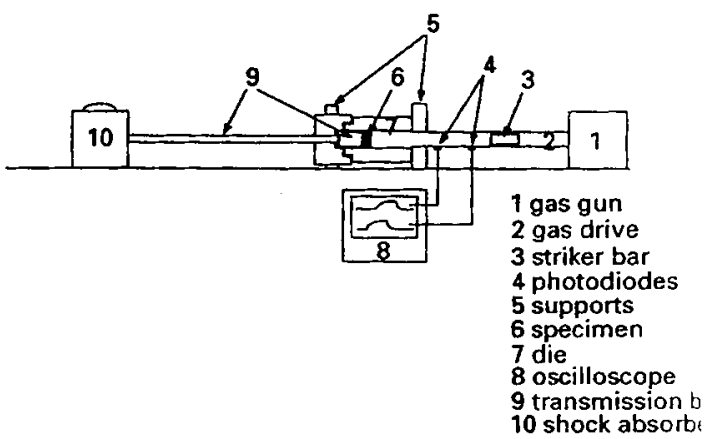

Figure 2 : Dynamic compaction system

\subsection{Compact characteristics}

Morphological features were examined by SEM. Relative density D, i.e the ratio of the apparent density of the compact to the true density of the powder, was calculated to express the compaction degree. Each compact was prepared with $4 \mathrm{~g}$ of powder and the true density of hydroxyapatite $\left(2.95 \mathrm{~g} / \mathrm{cm}^{3}\right)$ was measured using an Accupyc 1330 helium-air pycnometer (micromeritics, USA). The maximum tensile strength was determined by a diametral compression test [18] :

$$
\sigma=2 \mathrm{P} / \pi \mathrm{De}
$$

$P$ : applied load $(\mathrm{N})$

$\mathrm{D}:$ specimen diameter $(\mathrm{mm})$

e : specimen thickness ( $\mathrm{mm}$ )

As controls, samples prepared by static compaction and sintered at $1,050^{\circ} \mathrm{C}$ were also tested (Table 1 ) 
Table 1: Elaboration parameters of the compacts.

\begin{tabular}{|c|c|c|c|c|}
\hline sample & number of samples & static precompaction (MPa) & sintering $\left(1,050^{\circ} \mathrm{C}\right)$ & projectile velocity $(\mathbf{m} / \mathbf{s})$ \\
\hline A & 4 & 155 & 1 & 1 \\
\hline B & 2 & 155 & $5 \min$ & $/$ \\
C & 5 & 62 & $20 \min$ & 1 \\
D & 1 & 62 & $30 \mathrm{~min}$ & 1 \\
E & 3 & 62 & $60 \min$ & $/$ \\
\hline F & 1 & 3 & 1 & 25 \\
G & 5 & 3 & 1 & 50 \\
\hline
\end{tabular}

\section{RESULTS AND DISCUSSION}

\subsection{Compaction parameters}

Degree of compaction and SEM observations of compacts elaborated using various static precompactions and stricker velocities ranging from 0 to $50 \mathrm{~m} / \mathrm{s}$ [19] showed that similar final compaction degrees were achieved regardless of the static precompaction used before firing. A high static precompaction resulted in large peripheral cracks, indicating inhomogenous densification.

With the present compaction system, the highest densities obtained with hydroxyapatite powder were about $70 \%$ (static precompaction of $310 \mathrm{MPa}$ and projectile velocity of $50 \mathrm{~m} / \mathrm{s}$ ). From the point of view of the powder-compaction industry, the remaining micropores might appear as a drawback. However, microporosity is necessary in biomaterials since it allows internal biological fluids circulation, thus promoting bioactivity, while retaining sufficient mechanical properties.

\subsection{Tensile strength}

As can be observed in figure 3, tensile strength depended on the compaction degree of the compacts. Mechanical strength improvement with sintering time (groups B to E) appears to be linked to the formation of bridges between particles. Indeed samples from group B had low compaction degree (53\%) indicating that no consolidation had occured but only particle reorganization. On the other hand sintering at $1,050^{\circ} \mathrm{C}$ during 60 minutes (group D) permitted the formation of interparticle boundaries in the compacts and the beginning of densification (compaction degree of 59\%) which resulted in higher tensile strength $(10.9 \pm 0.8 \mathrm{MPa})$. Since compacts obtained by dynamic compaction with a projectile velocity of $50 \mathrm{~m} / \mathrm{s}$ (group $\mathrm{G}$ ) possessed similar tensile strength $(12.4 \pm 2.7 \mathrm{MPa}$ ) as sintered compacts from group $\mathrm{D}$, it is suggested that dynamic compaction had created interparticle boundaries.

\section{CONCLUSION}

Dynamic compaction of hydroxyapatite powder at particle velocities of about $50 \mathrm{~m} / \mathrm{s}$ produced compacts with a $65 \%$ compaction degree and a tensile strength of about $12.4 \mathrm{MPa}$. This tensile strength was close to that of sintered compacts which indicated that interparticle boundaries had been created during dynamic compaction. As this process does not require any external heat for powder consolidation, dynamic compaction was used to produce drug-loaded calcium phosphate ceramics. Indeed it has been shown in a previous study that human growth hormone and vancomycin were not denaturated during shock compaction [20]. In vitro study also demonstrated that the biological activity of human growth hormone was totally preserved after dynamic compaction [21]. Therefore this compaction process appears useful to produce biomaterials incorporating a therapeutic agent. The kinetics of release of the therapeutic agent could be modified by changing either the material solubility or the compact porosity. 


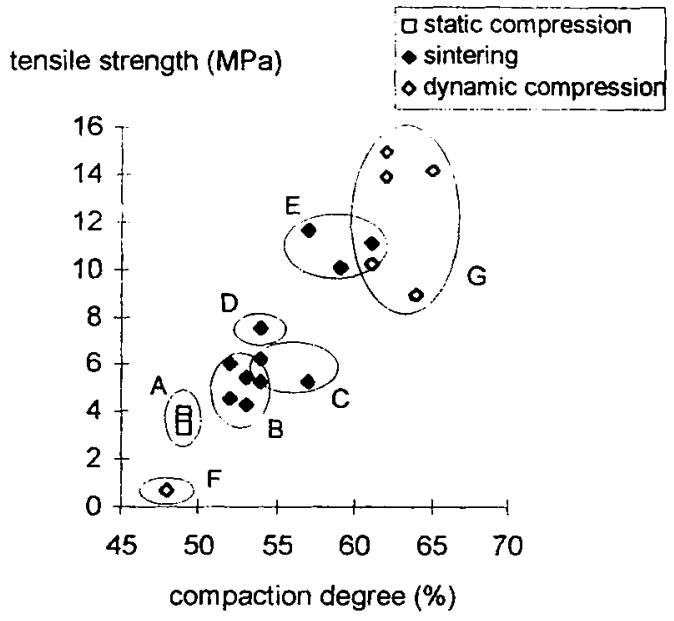

Figure 3: Tensile strength as a function of compaction degree

\section{Acknowledgments}

This work was supported by the ANVAR, CNRS EP 59 and INSERM CJF 93-05.

\section{References}

[1] Daculsi G., LeGeros R.Z., Nery E. et al., J Biomed Mater Res, 23 (1989) 883-894.

[2] Daculsi G., Passuti N., Martin S. et al., J Biomed Mater Res, 24 (1990) 379-396.

[3] De Groot K., Biomaterials, 1(1980) 47-50.

[4] Van Blitterswijk C.A., Grote J.J., Kuijpers W. et al., Biomaterials, 7 (1986) 137-143.

[5] Best S., Bonfield W. et Doyle C., Proceedings of the $1^{\text {st }}$ International Bioceramic Symposium (Dorishi H., Aoki H., Sawai K., Ishiyako America Inc., 1989) p. 68.

[6] Bigi A., Incerti A., Roveri N. el al., Biomaterials 1 (1980) 140-144.

[7] Bohne W., Pouëzat J.A., Peru L. et Daculsi G., Cells and Materials 3 (1993) 419-424.

[8] Krajewski A et Ravaglioli A.1, Biomaterials 2 (1981) 105-111.

[9] Es-Saheb M.H., J. Mat. Sci. 27 (1992) 4151-4159.

[10] Ferreira A., Meyers M.A., Thadhani N.N. et al., Metall. Trans. A 22A (1991) 685-695.

[11] Ferreira A., Meyers M.A. et Thadhani N.N., Metall. Trans. A 23A (1992) 3251-3261.

[12] Meyers M.A., Wang S.L., Acta Metall. 36 (1988) 925-936.

[13] Morimoto Y., Hayashi T. et Nakanishi A., Inst. Phys. Conf. Ser, No 70, paper presented at 3rd Conf. Mech. Prop. High Rates of Strain, Oxford (1984) 427-434.

[14] Morris D.G., Metal. Sci. 15 (1981) 116-124.

[15] Page N.W et. Raybould D., Mat. Sci. Eng. A118 (1989) 179-195.

[16] Raybould D., J. Mat. Sci. 16 (1981) 589-598.

[17] Raybould D., J. Mat. Sci. 19 (1984) 3498-3514.

[18] Mordfin L., Kerper M.J., "Mechanical and thermal properties of ceramics ", Symposium on the mechanics and thermal properties of ceramic proceedings (1968) pp 243-262.

[19] Trécant M., Daculsi G. et Leroy M., J. Mater. Sci. : Mater. in Med. 6 (1995) 545-551.

[20] Trécant M., Guicheux J., Grimandi G. et al., Biomaterials 18 (1997) 141-145.

[21] Guicheux J., Heymann D., Trécant M. et al., J. of Biomed. Mater. Res. in press 